Jurnal Konstruksi Hukum | ISSN: XXXX | E-ISSN: XXXX Vol. 1, No. 2, Oktober 2020, Hal. 251-254| Available online at https://www.ejournal.warmadewa.ac.id/index.php/jukonhum

DOI: https://doi.org/10.22225/jkh.1.2.2594.251-254

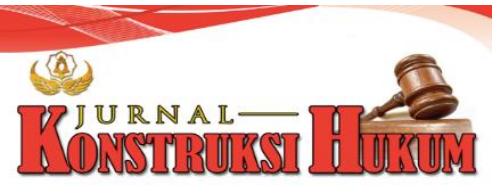

\title{
WEWENANG NOTARIS DALAM PEMBUATAN AKTA NOTARIL TERHADAP TANAH HAK GUNA BANGUNAN DI ATAS TANAH HAK MILIK UNTUK PEMBANGUNAN HOTEL
}

\author{
Anak Agung Made Wahyu Purwanta, I Nyoman Sumardika, Ni Gusti Ketut Sri Astiti \\ Fakultas Hukum Universitas Warmadewa, Denpasar-Bali, Indonesia
}

\begin{abstract}
Abstrak
Hak guna bangunan dapat diberikan di atas tanah hak milik dan pemberian hak guna bangunan atas tanah hak milik dibuat dengan akta pejabat pembuat akta tanah (selanjutnya disebut Akta PPAT) bukan dengan akta yang dibuat di hadapan Notaris (selanjutnya disebut Akta Notaril), dimana nantinya Akta PPAT tersebut akan didaftarkan pada kantor pertanahan. Seorang notaris dalam pandangan masyarakat dianggap sebagai seorang pejabat, tempat seseorang memperoleh nasehat hukum yang boleh diandalkan, tempat pembuatan dokumen hukum yang kuat dalam suatu proses hukum yang akan dilakukan khususnya dalam membuat akta perjanjian untuk pembanggunan hotel. Penelitian ini bertujuan untuk mengetahui wewenang notaris dalam pembuatan akta notarial terhadap tanah hak guna bangunan di atas tanah hak milik untuk pembangunan hotel, yang kedua bagaimanakah eksistensi akta notarial dalam pemberian hak guna bangunan di atas tanah hak milik untuk pembangunan hotel. Jenis penelitian yang digunakan dalam penelitian ini yaitu penelitian hukum normatif, sumber data berdasarkan bahan-bahan hukum primer, bahan hukum sekunder dan bahan hukum tersier. Pendekatan yang digunakan dalam penelitian ini adalah pendekatan perundang - undangan. Teknik pengumpulan data hukum yakni dengan studi kepustakaan. Hasil dalam penelitian yang pertama tugas jabatan notaris adalah memformulasikan keinginan atau tindakan para pihak ke dalam akta otentik, sehingga untuk menjalankan tugasnya seorang notaris harus tetap berpedoman pada peraturan yang berlaku, yang kedua Eksistensi akta notaril dalam pemberian hak guna banggunan di atas tanah hak milik untuk pembanggunan hotel keberadaan akta notaril dalam pemberian hak guna bangunan di atas tanah milik untuk pembangunan hotel memiliki sifat yang positif karena ada persyaratan yang sangat penting yaitu suatu alat bukti atas kepemilikan mengenai tanah, serta bangunan yang ada diatasnya secara formil atau tertulis dalam bentuk sertifikat
\end{abstract}

Kata Kunci: Akta Notaril; Hak Guna Bangunan; Notaris

\begin{abstract}
The building right can be given on land with ownership rights and the granting of rights to build on land with ownership rights is made with the deed of the official land deed maker (hereinafter referred to as the PPAT Deed) instead of the deed made before a Notary (hereinafter referred to as the Notary Deed), where the Deed The PPAT will be registered at the land office. A notary in the view of society is considered an official, a place for someone to obtain reliable legal advice, a place for making strong legal documents in a legal process that will be carried out, especially in making a deed of agreement for hotel development. This study aims to determine the authority of the notary in making a notarial deed of land use rights on land for hotel development, second, how is the existence of a notarial deed in granting building use rights over land of ownership for hotel construction. The type of this research is normative legal research, data sources based on primary legal materials, secondary legal materials and tertiary legal materials. The approach used in this research is a statutory approach. The technique of collecting legal data is literature study. The results in the research are the task of the notary office is to formulate the wishes or actions of the parties into an authentic deed, so that to carry out its duties a notary must adhere to the applicable regulations, secondly the existence of a notary deed in granting development rights over land of ownership rights for hotel development, the existence of a notary deed in granting the right to build on land owned for hotel construction has a positive character because there are very important requirements, namely an evidence of ownership of land, as well as the building on it in a formal or written form of a certificate
\end{abstract}

Keywords: Notary deed; Building rights; Notary Public 


\section{PENDAHULUAN}

Perkembangan pembanggunan di Bali sudah tentu membutuh tanah yang luas. Luas tanah tidak akan pernah bertambah sehingga muncul suatu pemikiran untuk membanggun secara vertical (keatas) seperti di bidang akomodasi pariwisata khususnya hotel. Pembangunan akomodasi pariwisata merupakan salah satu pembangunan yang perlu dikembangkan karena dari sektor ini dapat meningkatkan penerimaan devisa negara, menghasilkan pertumbuhan ekonomi yang cepat dalam menyediakan lapangan kerja, peningkatan penghasilan, standar hidup serta menstimulasikan faktor-faktor produksi yang lainnya (Urbanus \& Febianti, 2017).

Tanah sebagai salah satu hal yang penting di Indonesia memiliki berbagai kegunaan, Kegunaan tanah tersebut yaitu sebagai rumah tempat tinggal, perkantoran, gedung-gedung, hotel, apartemen, supermarket, rumah sakit, taman perkotaan (Ramadhan \& Ngadino, 2019). Salah satu objek pembanggunan hotel yaitu di banggun diatas tanah Hak Guna Bangunan Atas Hak Milik. Suatu hak yang diberikan agar bisa mendirikan atau memiliki suatu bangunan yang ada diatas tanah yang tidak merupakan milik sendiri dalam jangka waktu yang ditentukan serta dengan luas tertentu disebut dengan hak guna bangunan. Mengenai pengaturan tentang jangka waktu Hak Guna Bangunan sebagaimana diatur dalam Peraturan Pemerintah Nomor 40 Tahun 1996 tentang HGU, HGB dan Hak Pakai Atas Tanah (selanjutnya disebut PP No. 40 Tahun 1996), yaitu maksimal 30 Tahun dengan perpanjangan 20 tahun dan dibolehkan untuk diperbaharui (Harsono, 2007).

Pemberian Hak Guna Bangunan ( HGB ) Atas Tanah Hak Milik sebagaimana dimaksud dikatakan bahwa Hak Guna Bangunan terjadi mengenai tanah milik, karenaperjanjian yang berbentuk otentik antara pemilik tanah yang bersangkutan dengan pihak yang akan memperoleh Hak Guna Bangunan itu, yang bermaksud menimbulkan hak tersebut (Lubis, 2007). Ketentuan diatas menunjukan bahwa Hak Guna Bangunan dapat diberikan diatas tanah Hak Milik dan pemberian Hak Guna Bangunan atas tanah Hak milik dibuat dengan Akta Pejabat Pembuat Akta Tanah (selanjutnya disebut Akta PPAT) bukan dengan Akta yang dibuat dihadapan Notaris (selanjutnya disebut Akta Notariil), dimana nantinya Akta PPAT tersebut akan didaftarkan pada kantor pertanahan. Namun pemberian Hak Guna Bangunan atas tanah Hak Milik dapat difasilitasi dengan Akta Notariil dalam bentuk Akta Perjanjian Pendahuluan Pemberian Hak Guna Bangunan atas tanah hak milik. Seorang notaris memiliki kewenangan untuk membuat suatu akta otentik berdasarkan Undang- undang (Arief et al., 2019). Sejak lahirnya hukum pembuktian lembaga kenotariatan sekarang dijadikan sebagai suatu lembaga yang dapat mengeluarkan suatu akta autentik. Penelitian ini bertujuan Untuk menganalisis kedudukan Notaris dalam membuat Akta Notariil dengan objek tanah Hak Guna Bangunan (HGB) atas tanah hak milik untuk pembangunan hotel dan Untuk menjelaskan eksistensi akta notariil yang dibuat dihadapan Notaris dalam pemberian hak guna bangunan atas tanah hak milik untuk pembangunan hotel.

\section{METODE PENELITIAN}

Jenis penelitian yang digunakan adalah Penelitian hukum normative yaitu suatu metode penelitian yang dibagi menjadi dua bagian, yakni pendekatan melalui peraturan perundang-undangan (statue) dan pendekatan melalui konseptual (comparative). Sumber bahan hukum yang digunakan dalam penelitian yaitu bahan hukum primer yaitu bahan hukum yang mempunyai kekuatan mengikat secara umum (perundang-undangan) atau mempunyai kekuatan mengikat bagi pihak berkepentingan (kontrak, konvesi, dokumen hukum, dan putusan hakim dan bahan hukum sekunder adalah semua publikasi tentang hukum yang merupakan dokumen tidak resmi. Teknik pengumpulan bahan hukum yakni dengan studi kepustakaan yang bersumber dari bahan-bahan hukum primer dan bahan hukum sekunder, bahan hukum yang digunakan yaitu berupa peraturan perundang-undangan terkait serta bahan hukum sekunder yang digunakan yaitu berupa doktrin-doktrin, literatur, ataupun buku para ahli yang berkaitan dengan permasalahan yang diteliti. Penelitian hukum merupakan suatu kegiatan ilmiah, yang didasarkan pada metode, sistemmatika dan pemikiran tertentu yang bertujuan untuk mempelajari sesuatu atau beberapa gejala hukum tertentu (Soekanto, 1984).

\section{HASIL DAN PEMBAHASAN}

\section{Kedudukan Notaris dalam Membuat Akta Notariil dengan Objek Tanah Hak Guna Bangun}

Notaris merupakan seseorang yang telah terpilih atau hasil dari pilihan Negara untuk pengambilan suatu sumpah, menjalankan suatu hal dalam dokumen, membuat sah suatu tanda tangan dari seseorang dan melaksanakan suatu tugas atau pekerjaan yang resmi dan telah ditentukan pada bidangnya (Afifah, 
2017). Sejak lahirnya hukum pembuktian lembaga kenotariatan sekarang dijadikan sebagai suatu lembaga yang dapat mengeluarkan suatu akta autentik. Adapun tugas dari seorang notaris yaitu mengikat hubungan dari para pihak yang ingin melkukan suatu kesepakatan yang dituangkan dalam sebuah akta yang bentuknya dibuat secara tertulis dan dengan format yang telah ditentukan, yang nantinya akta itu akan menjadi akta otentik. Notaris merupak seseorang yang membuat dokumen yang nantinya akan menjadi alat pembuktian dalam proses hukum maka disinilah letak arti penting bagi seorang notaris a notaris karena Undang-undang diberi wewenang membuat suatu alat pembuktian yang sempurna, dalam pengertian bahwa apa yang tersebut dalam akta autentik itu pada pokoknya dianggap benar sepanjang tidak ada pembuktian sebaliknya. Oleh karena tugas jabatan notaris bagaimanapun tugas dari seorang notaris, semua notaris yang ada diberikan harapan agar selalu menjunjung luhur dari harkat dan martabatnya dan tugas selanjutnya merupakan pekerjaan jabatannya serta menjalnkan tugas dengan memenuhi persyaratan yang ditentukan oleh perundang-undangan.

Tugas notaris terkait dengan membuat akta notariil terhadap tanah Hak Guna Bangunan diatas tanah Hak Milik untuk pembangunan hotel (Paramarta et al., 2017). Notaris dapat memberikan jaminan atau alat bukti serta perlindungan hukum terhadap keadaan, pariwisata hukum, perbuatan hukum yang akan dilakukan agar para pihak yang terlibat didalamnya mendapat kepastian hukum dengan maksud untuk membantu dan melayani masyarakat yang membutuhkan dengan melahirkan produk hukum yaitu alat bukti tertulis atau akta notariil yang bersifat otentik

Untuk dapat membenarkan suatu kesalahan itu nanti dibuat berita acara pembenaran dan para pihak juga berhak untuk mengetahui atas salinan yang dibuat itu dan notaris mempunyai kewajiban untuk menyampaikannya (Hably \& Djajaputra, 2019). Apabila ada seorang notaris melakukan perbuatan yang bukan merupakan kewenangannya maka dapat dikatakan bahwa notaris tersebut telah melakukan perbuatan diluar kewenangannya. Jika seorang notaris melakukan perbuatan yang diluar kewenangannya maka suatu produk atau akta yang telah dibuatnya tersebut tidak dapat dikatakan mengikat secara hukum dan akta yang telah dibuatnya itu tidak bisa mengikat para pihak secara hukum, serta apabila ada pihak atay para pihak yang dirugikan akibat dari perbuatan notaris yang dilakukan diluar kewenangannya maka para pihak tersebut juga bisa mengajkan gugatan atas dasar kerugian itu ke pengadilan Negeri.

Pemberian hak guna bangunan atas tanah hak milik untuk pembanggunan hotel, bahwa Hak Guna Bangunan dapat diberikan diatas tanah Hak Milik dan pemberian Hak Guna Bangunan atas tanah Hak Milik dibuat dengan Akta PPAT bukan dengan akat Notariil, diaman nantinya akta PPAT tersebut akan didaftarkan pada kantor pertanahan. Dalam praktiknya suatu akta yang dibuat dengan notaris merupakan relas ataupun akta berita acara yang di dalamnya berisikan mengenai uraian dari notaris yang disaksikan langsung oleh notaris bersangkutan beserta para pihak dan atas permintaan dari para pihak tersebut supaya apapun perbuatan dan tindakan dari para pihak dituangkan dalam suatu akta yang disebut akta notaris. Pada dasarnya akta yang dibuat oleh notaris merupakan akta pihak, dalam akta itu berisikan cerita atau uraian-uraian serta keterangan dari para pihak, pernyataan dari para pihak dihadapan notaris.

\section{Eksistensi Akta Notariil dalam Pemberian Hak Guna bangunan Atas Tanah Hak Milik untuk Pembangunan Hotel}

Dalam pembuatan akta seorang notaris bisa memberi masukan atau saran pada para pihak, akan tetapi diterima atau tidaknya saran itu merupakan keputusan dari para pihak, karena yang nantinya akan dituangkan dalam suatu akta adalah apa yang berdasarkan keinginan dan permintaan dari para pihak tersebut, melainkan tidak saran ataupun masukan dari notaris yang akan digunakan (Ningsih dkk., 2019). Apabila suatu saat nanti para pihak mempermasalahkan isi dari akta itu maka notaris tidak ada sangkut pautnya. Karena karena posisi notaris dalam akta memang diluar dari para pihak dan tidak merupakan pelaku didalamnya. Notaris dalam hal ini bisa menjadi seorang tergugat atau turut tergugat apabila notaris melakukan perbuatan diluar kewenangannya, yaitu contohnya memalsukan keterangan dalam akta otentik. Selain itu notaris juga bisa menjadi tergugat atau turut tergugat jika ada akta yang ada kaitannya dengan akta yang dibuat oleh atau di depan notaris, maka permasalahan seperti itu dapat mncederai suau akta yang telah dibuatnya. Seorang notaris hanya membuat akta berdasarkan kesepakatan para pihak, keinginan, serta permintannya.

Kegunaan tanah tersebut yaitu sebagai rumah tempat tinggal, perkantoran, gedung-gedung, hotel, apartemen, supermarket, rumah sakit, taman perkotaan (Ramadhan \& Ngadino, 2019). Dalam 
pengalihan hak atas tanah atau pemindahan hak dapat terlihat melalui karakteristik dan prosedur pada saat proses pengalihannya, disana terdapat suatu unsur-unsur hukum yang menjadi pembeda, paling penting yang berkaitan dengan persyaratan formilnya dan materiilnya, juga pada prosedurnya ataupun dari keadaan dan sifat yang akan sangat menentukan mekanismenya dalam menentukan subyek dan obyeknya. Akan tetapi selain persyaratan yang telah disebutkan di atas ada juga persyaratan yang tak kalah pentingnya yaitu harus mempunyai bukti dari kepemilikan tanah yaitu bukti dari hak kepemilikan dalam bentuk tulisan atau disebut dengan syarat formil berupa "sertifikat "sebagai bukti tanah yang yang sudah terdaftar ataupun bukti pendukung lainnya jika tanah belum terdaftar atau belum memiliki sertifikat. Bukti-bukti selain sertifikat dapat juga berupa suatu akta ataupun surat keputusan telah memberikan hak untuk suatu tanah serta bangunannya. Sehingga hal itu dapat dijadikan sebagai suatu kepastian secara hukum untuk membuktikan legalitas pengalihan suatu ha katas tanah sesuai dengan peraturan perundang-undangan yang masih berlaku.

\section{SIMPULAN DAN SARAN}

\section{Simpulan}

Dari hasil dan pembahasan penelitian maka dapat disimpulkan yaitu:

1) Tugas jabatan Notaris adalah memformulasikan keinginan/ tindakan para pihak ke dalam akta otentik. Dalam melaksanakan tugasnya, seorang notaris harus mempunyai kemampuan serta pendidikan yang khusus untuk dapat melaksanakan tugasnya. Maka dari itu untuk menjalankan tugasnya seorang notaris harus tetap berpedoman pada peraturan yang berlaku.

2) Eksistensi akta notariil dalam pemberian hak guna banggunan diatas tanah hak milik untuk Pembanggunan Hotel keberadaan akta notaril dalam pemberian hak guna bangunan diatas tanah milik untuk pembangunan hotel memiliki sifat yang positif karena ada persyaratan yang sangat penting yaitu suatu alat bukti atas kepemilikan mengenai tanah, serta bangunan yang ada diatasnya secara formil atau tertulis dalam bentuk sertifikat, jika tidak ada sertifikat berarti tanah itu belum terdaftar dan diperlukan bukti pendukung lainnya untuk bisa membuktikan atas hak kepemilikan tersebut.

\section{Saran}

Adapun saran yang bisa diberikan oleh peneliti sebagai berikut:

1) Pejabat Notaris dapat sebaiknya menegaskan lagi peraturan tentang eksistensinya akta notaril dalam pembuatan akta tanah baik dalam pembangunan untuk hak milik maupun hak guna pakai.

2) Notaris seharusnya menjelaskan tentang akta notaril itu seperti apa kepada para pihak yang akan membuat akta notaril dan mengerti bahwa menjamin bagaimana kepastian.

\section{DAFTAR PUSTAKA}

Afifah, K. (2017). Tanggung Jawab dan Perlindungan Hukum bagi Notaris secara Perdata terhadap Akta yang Dibuatnya. Lex Renaissance, 1(2), 147-161.

Arief, A. N. R., Akub, S., \& Muchtar, S. (2019). Persetujuan Majelis Kehormatan Notaris Wilayah dalam Pengambilan Minuta Akta dalam Proses Peradilan. Al-Adalah: Jurnal Hukum Dan Politik Islam, 4(1), 5281

Hably, R. U., \& Djajaputra, G. (2019). Kewenangan Notaris dalam Hal Membuat Akta Partij. Jurnal Hukum Adigama, 2(2), 482.

Harsono, B. (2007). Hukum Agraria Indonesia. Djmbatan.

Lubis, M. Y. A. R. L. (2007). Kepemilikan Properti di Indonesia. Mandar Maju.

Ningsih, A., Faisal, \& Adwani. (2019). Kedudukan Notaris sebagai Mediator Sengketa Kenotariatan Terkait dengan Kewajiban Penyuluhan Hukum. Mimbar Hukum, 27(1), 15-28.

Paramarta, I. W., Widhiyanti, H. N., \& Endah, S. N. (2017). Pertanggungjawaban Notaris Berkenaan dengan Kebenaran Substansi Akta Otentik. Rechtidee, 12(2), 267-285.

Ramadhan, D., \& Ngadino. (2019). Kewenangan Notaris dalam Pembuatan Akta yang Berhubungan dengan Pertanahan. 12(2), 679-690.

Soekanto, S. (1984). PengantarPenelitianHukum. UI Press.

Urbanus, N., \& Febianti. (2017). Analisis Dampak Perkembangan Pariwisata terhadap Perilaku Konsumtif Masyarakat Wilayah Bali Selatan. Jurnal Kepariwisataan Dan Hospitalitas, 1(No.2), 118-133. 